\title{
КЛАСИФІКАЦІЯ КІБЕРЗЛОЧИНІВ У КРИМІНАЛІСТИЦІ
}

Довженко О. Ю.

У науковій статmі розглянуто різноманітні підходи до класифікації кіберзлочинів у криміналістиці. Зокрема, такі підходи можуть ґрунтуватися на характері злочинного посягання, його способі чи суб'єкті злочину. Найбільш поширеною є класифікація за об'єктом злочину. Поєднання такої класифікації з наявним поділом злочинів за чинним Кримінальним кодексом дало змогу запропонувати власну оригінальну класифікацію.

Ключові слова: кіберзлочини, класифікачія кіберзлочинів, об'єкт кіберзлочинів, суб'єкт кіберзлочинів, предмет кіберзлочинів.

В научной литературе рассматриваются различные подходы к классификации киберпреступлений в криминалистике. Среди прочего, такие подходы могут основываться на характере преступного посягательства, его способе или субъекте преступления. Наиболее распространённой является классификация по объекту преступления. Объединение такой классификации с существующим разделением преступлений по действующему Уголовному кодексу позволило предложить собственную оригинальную классификацию.

Ключевые слова: киберпреступления, классификация киберпреступлений, объект киберпреступлений, субъект киберпреступлений, предмет киберпреступлений.

The classification of cybercrimes is subject to extensive dispute in the scientific literature. Several approaches have been proposed by the researchers. They can be based on the method of cybercrime or subject of criminal offence. The latter differentiates between crimes committed by inexperienced users, experienced users and those requiring specific knowledge, which can be committed only by persons possessing special computer education and skills. However, the most widely recognized classification is based on the object of crime. This object can consist of computer data (crimes like stealing of data or use of malware), property rights exercised with the use of computer technology (like bank transactions), personal rights of individuals (like right to dignity or property and related rights) and others. These classifications are yet of importance rather for the theory of criminalistics. From the point of view of practical criminalistic action, they may be problematic as they do not correspond to the existing provisions of Ukrainian criminal law, including to classification of crime under the Criminal Code of Ukraine. The combination of the object-based approach with the existing classification of crime under the Criminal Code of Ukraine enabled proposition of an original classification that is based on the sections of the Code. It includes crimes against personal rights of individuals, human dignity, property, public morals and against the State. Although imperfect, this classification can be applicable in practice with consideration of the existing state of law and useful from the point of view of the law on criminal procedure for formal affirmation of criminalistic action.

Key words: cybercrimes, classification of cybercrimes, object of cybercrimes, subject of cybercrimes, matter of cybercrimes.

Постановка проблеми та їі актуальність. Кіберзлочини $є$ порівняно новим феноменом для кримінального права й криміналістики. Відсутнє навіть точне визначення цього поняття, проте наявне розуміння, що з'явилася нова категорія злочинів, що здійснюються в кіберпросторі та становлять не меншу загрозу, ніж «традиційні» злочини. На рівні міжнародної спільноти прийнято ряд нормативно-правових актів, спрямованих на боротьбу з кіберзлочинами. Водночас ця боротьба утруднюється відсутністю задовільної дефініції та невизначеністю того які саме злочини мають бути віднесені до цієї категорії. Розв'язанню цих питань сприятиме проведення класифікації злочинів, що в нормативно-правових актах та літературі відносяться до категорії кіберзлочинів. Крім того, така класифікація сприятиме розробці норм кримінального та кримінального процесуального права, спрямованих на боротьбу з такими злочинами.

Аналіз останніх досліджень і публікацій демонструє певний інтерес дослідників до даної теми та початок іï розробки в літературі. Зокрема, слід виділити дисертацію Є.С. Шевченко, в якому приділено увагу криміналістичній класифікації кіберзлочинів, наукові розвідки, проведені Ю.М. Піциком (провів класифікацію кіберзлочинів проти власності), О.Ю. Іванченко, В.В. Семеновою, О.В. Амеліною та іншими дослідниками. Водночас зберігається потреба в подальшому дослідженні вказаної проблематики, адже загальновизнана класифікація кіберзлочинів, що може бути використана для розробки відповідних норм кримінального права, досі відсутня. Крім того, саме явище кіберзлочинності перебуває у постійному розвитку, через що надати повну та вичерпну класифікацію всіх можливих кіберзлочинів наразі навряд чи можливо. Завданням дослідника $\epsilon$ відстеження всіх проявів кіберзлочинності та постійне вдосконалення класифікації кіберзлочинів з урахуванням нових тенденцій.

Мета статті полягає в тому, аби дослідити запропоновані класифікації кіберзлочинів, підстави такої класифікації та на їхній основі запропонувати нову зведену класифікацію.

Виклад основного матеріалу. Процес класифікації передбачає розподіл явищ, що розглядаються, за групами чи класами, що полегшує їхню систематизацію. 3 криміналістичної точки зору, систематизації підлягає весь обсяг накопиченого криміналістичного наукового знання та виділена з нього система криміналістичних понять [1, с. 72]. Це дає змогу встановити загальне уявлення про певну групу явищ, співставити окремі явища та групи явищ між собою, виділити закономірності та прогнозувати можливості розвитку явищ, що розглядаються, в тому чи іншому напрямку. Отже, криміналістична класифікація дозволяє піднести розуміння об'єкту дослідження на новий рівень через проникнення до його сутності, забезпечує виявлення закономірностей, необхідних для його наукового обґрунтування та опису. Водночас вона дає змогу виявити мало досліджені та непізнані сторони системи, що розглядається та слугує необхідною ланкою в розслідуванні протиправних діянь [8, с. 39]. Криміналістична класифікація злочинів 
отримує практичне застосування в ході слідчої діяльності, адже вона забезпечує вірне розуміння сутності подій, що розслідуються, вибір та застосування методики розслідування окремих видів злочинів.

Під час проведення класифікації кіберзлочинів доцільно звернутися до міжнародних документів, в першу чергу до Конвенції Ради Європи про кіберзлочинність [4]. Нею правопорушення в кіберсфері розподіляються на чотири групи (пізніше Додатковим протоколом було виділено ще п'яту групу) [2]. Класифікацію за Конвенцією можна вважати еталонною, адже наявні міжнародні та регіональні нормативно-правові акти та наукова практика зорієнтовані на прийнятий Конвенцією розподіл комп'ютерних злочинів.

Перша група кіберзлочинів включає протиправні діяння, що посягають на конфіденційність, цілісність та недоступність комп'ютерних даних й систем, таких як несанкціонований доступ, незаконне перехоплення, втручання в бази даних і в систему. Другу групу становлять злочини, пов'язані з використанням комп'ютерів як засобу здійснення протизаконних дій, тобто засобу маніпуляції з інформацією. До них можна віднести комп'ютерне шахрайство та комп'ютерне підроблення. Третя група - кіберзлочини, пов'язані зі змістом даних, що розміщені в комп'ютерних мережах. Найбільш розповсюдженим та найбільш суворо переслідуваним з таких злочинів $\epsilon$ діяння, пов'язані 3 дитячою порнографією. Четверту групу злочинів становлять злочини, пов'язані з порушенням авторського права та суміжних прав, при чому встановлення таких правопорушень Конвенцією віднесено до компетенції національних держав. Нарешті, п'ята група, що була запроваджена Додатковим протоколом складається з актів расизму та ксенофобії, що скоєні за допомогою комп'ютерних мереж.

Розв'язання цілого ряду завдань в процесі виявлення та розслідування кіберзлочинів залишалося б досить проблематичним без опори на криміналістичну класифікацію. Зростаюча статистика і різноманіття кіберзлочинів вимагає їх систематизації за різними підставами. Можна виділити декілька запропонованих дослідниками підходів.

Наприклад, Д.А. Ілюшин пропонує класифікацію кіберзлочинів за способами скоєння. На його думку, до кіберзлочинів можна віднести наступні типи злочинних посягань:

1. Неправомірне підключення до мережі Інтернет, a came:

неправомірне отримання та використання чужих даних для доступу до мережі Інтернет (логіну та паролю);

неправомірне отримання й використання облікових власних облікових даних на чужих електронних приладах чи з використанням чужої MAC та IP адреси з метою неправомірного доступу до мережі Інтернет;

неправомірне підключення до мережі оператора електронного зв'язку з метою ухилення від сплати послуг, отриманих в мережі Інтернет.

2. Створення, використання та розповсюдження мережевих шкідливих комп'ютерних програм.

3. Незаконне виготовлення, зберігання, розповсюдження, рекламування чи публічна демонстрація інформації, що заборонена до вільного обігу, за допомогою мережі Інтернет. незаконне виготовлення, зберігання, розповсюдження, рекламування та публічна демонстрація порнографічних матеріалів, скоєна з використанням мережі Інтернет;

незаконне отримання та розголошення відомостей, які складають комерційну, податкову чи банківську таємницю, скоєне з використанням мережі Інтернет;

порушення таємниці переписки, телефонних розмов, поштових чи інших повідомлень, що здійснюється за допомогою мережі Інтернет;

образа, нанесена шляхом розповсюдження неправдивих відомостей на інформаційних ресурсах в мережі Інтернет;

збудження ненависті чи ворожнечі, а також приниження людської гідності, скоєні за допомогою мережі Інтернет.

4. Порушення авторських та суміжних прав, а також незаконне використання товарних знаків за допомогою мережі Інтернет.

5. Шахрайство, скоєне в сфері надання послуг Інтернет.

продаж неіснуючих товарів, фіктивних послуг та пропозиція фіктивної роботи, скоєні за допомогою мережі Інтернет;

залучення коштів до удаваної благодійності; шахрайство в електронних платіжно-розрахункових системах мережі Інтернет;

шахрайство в інтернет-казино, букмекерських конторах, в розіграшах лотерей та на аукціонах;

шахрайство, скоєне з використанням фіктивних шлюбних інтернет-агенцій;

створення фінансових пірамід з використанням мережі Інтернет.

6. Викрадення електронних реквізитів та продаж підроблених кредитних чи розрахункових карт.

7. Незаконне підприємництво в сфері надання послуг в мережі Інтернет;

8. Вимагання за допомогою мережі Інтернет.

9. Кібертероризм [3].

Як можна помітити, Д.А. Ілюшин дотримується підходу, відповідно до якого кіберзлочинами слід вважати злочини, скоєні за допомогою глобальної мережі. Іншої точки зору дотримується Д.В. Пашнев, який пропонує класифікацію кіберзлочинів через засоби їхнього скоєння та злочинну ціль. Відповідно до цієї класифікації, кіберзлочини поділяються наступним чином.

1. Злочини, в яких засоби комп'ютерних технологій $\epsilon$ основною метою посягання, тобто посягання здійснюється з метою знищення, викривлення, блокування чи порушення встановленого порядку маршрутизації комп'ютерної інформації, суттєвого порушення порядку роботи комп'ютерних систем та мереж.

2. Злочини в яких засоби комп'ютерних технологій $\epsilon$ проміжною метою, тобто шляхом вказаних впливів на них досягається інша ціль, така як присвоєння чужого майна, нелегальне отримання інформації, тощо.

3. Злочини при скоєнні яких засоби комп'ютерних технологій $є$ лише автоматизованим засобом протиправного діяння, такі як фальшивомонетництво, підробка документів, печатей, штампів, бланків цінних паперів, знаків поштової сплати, квитків, марок акцизного збору, розповсюдження незаконної інформації, завідомо неправдиві повідомлення про загрози суспільній безпеці, знищення чи пошкодження об'єктів власності, тощо. 

та науково-методичне забезпечення

4. Злочини в яких комп'ютерні технології $€$ засобом інформаційного забезпечення злочинної діяльності, такі як незаконний збір і систематизація інформації, ведення подвійної бухгалтерії, ведення баз даних щодо предметів, вилучених чи обмежених в цивільному обігу, зайняття сутенерством [6, с. 164-166].

Своєрідну класифікацію злочинів, що скоєні за допомогою електронних платіжних систем, пропонують О.М. Яковлев та Н.В. Оліндер. Як підстави класифікації ними використовуються об'єкт і предмет злочинного посягання, кількість суб'єктів злочину, ознака територіальності та спосіб скоєння злочину.

За об'єктом злочинного посягання виділяються злочини, скоєні з використанням платіжних засобів та систем:

злочини проти власності (шахрайство, крадіжка, вимагання);

злочини в сфері економічної діяльності (легалізація доходів, отриманих злочинним шляхом, незаконне підприємництво);

злочини в сфері комп'ютерної інформації (неправомірний доступ до комп'ютерної інформації, створення та розповсюдження шкідливих програм, призначених для здійснення неправомірних дій);

злочини проти державної влади, інтересів державної служби й служби в органах місцевого самоврядування (дача чи отримання хабаря з використанням електронних платіжних засобів).

За предметом злочинного посягання автори виділяють злочини, що мають матеріальний предмет посягання та злочини, що не мають такого предмету. За кількістю суб'єктів виділяють злочини скоєні однією особою та групою осіб. За способом скоєння - скоєні зі зловживанням вразливості електронної платіжної системи та з використанням реквізитів легального користувача електронної платіжної системи [9, с. 134-135].

В.О. Мещеряков пропонує ще одну підставу для криміналістичної класифікації кіберзлочинів - об'єкт злочинного посягання, під яким він розуміє комп'ютерну інформацію як складний багаторівневий об'єкт, який складається $з$ набору елементарних операцій на кожному рівні. Виходячи з цього, вчений виділяє наступні види злочинів:

знищення (порушення) комп'ютерної інформації; неправомірне заволодіння комп'ютерною інформацією чи порушення виключного права на іï використання;

дії чи бездіяльність зі створення (генерації) комп'ютерної інформації з заданими властивостями; неправомірна модифікація комп'ютерної інформації [5, с. 76-77].

Ще одну цікаву класифікацію пропонує А.Е. Серьожкіна. П̈ї підхід ґрунтується на особистості злочинця і його рівні професіоналізму у користуванні комп'ютерними системами. Виходячи з цього, дослідниця пропонує поділити користувачів кримінальних кібертехнологій на три групи:

1. Професійні користувачі, тобто спеціалісти, для яких комп'ютер $\epsilon$ предметом діяльності чи засобом та передумовою діяльності, або інструментом для розв'язання професійних завдань.

2. Користувачі, що не володіють навичками програмування, які використовують програмні продукти, що не вимагають таких навичок.
3. Випадкові користувачі, тобто дилетанти, які стикаються з комп'ютером вперше і здатні користуватися лише елементарними програмними продуктами [7, с. 16-17].

Розвиваючи цю думку, Є.С. Шевченко пропонує класифікацію кіберзлочинів, що ґрунтується на критерії рівня кваліфікації користувача (суб'єкта злочину) та його можливостей у виборі злочинних інформаційних технологій.

1. Злочини, скоєні з використанням найпростіших інформаційних технологій. Таке протиправне діяння може бути здійснене навіть випадковим користувачем на не вимагає наявності в злочинця кримінальних навичок та професійних знань в галузі телекомунікаційних технологій, а саме:

незаконне отримання й розголошення відомостей, що складають комерційну, податкову чи банківську таємницю;

незаконний збір чи розповсюдження інформації про приватне життя особи, яка складає його особисту чи сімейну таємницю;

збудження ненависті чи ворожнечі, приниження людської гідності;

порушення авторських та суміжних прав;

шахрайство (зокрема через фіктивні шлюбні агенції);

вимагання, скоєне з використанням мережі Інтернет;

окремі види кібертероризму (спонсорування та пропаганда терористичної діяльності.

2. Злочини, скоєні досвідченим користувачем із використанням інформаційних технологій середнього рівня. Такий злочин здатен скоїти професійний користувач, що не володіє навичками програмування, проте скоєння таких злочинів вимагає наявності певних професійних чи кримінальних навичок. Зокрема до них належать:

неправомірне підключення до мережі оператора електрозв'язку з метою ухилитися від сплати отриманих послуг мережі Інтернет;

незаконне виготовлення, зберігання, розповсюдження, рекламування чи публічна демонстрація інформації, забороненої до вільного обігу, що скоюється з використанням мережі Інтернет;

порушення авторських і суміжних прав, скоєне з використанням мережі Інтернет (незаконне розповсюдження екземплярів комп'ютерних програм, баз даних, аудіовізуальних чи літературних творів);

продаж неіснуючих товарів, надання фіктивних послуг та пропозиція фіктивної надомної роботи, скоєні з використанням мережі Інтернет;

залучення коштів на удавані благодійні цілі;

шахрайство в мережі Інтернет, зокрема в онлайн казино, букмекерських конторах, лотереях;

фінансові Інтернет-піраміди;

кібертероризм.

3. Злочини, скоєні користувачем який володіє спеціальними фаховими знаннями з використанням складних інформаційних технологій, що передбачають використання технологічних методів та їхню адаптацію до цілей злочинної діяльності. Такі злочини вимагають глибоких професійних знань та навичок. До них можна віднести такі:

неправомірне отримання й використання чужих облікових даних (логінів, паролів) для доступу до мережі Інтернет; 
часткову підміну власних облікових даних чужими для неправомірного доступу до мережі Інтернет; створення, використання й розповсюдження шкідливих мережевих комп'ютерних програм; незаконне отримання й розголошення відомостей, що становлять комерційну, податкову чи банківську таємницю, скоєне з використанням мережі Інтернет; порушення авторських й суміжних прав шляхом незаконного створення екземплярів комп'ютерних програм, баз даних, аудіовізуальних та літературних витворів; шахрайство в електронних платіжно-розрахунко-

вих системах мережі Інтернет; викрадення електронних реквізитів та збут підро-

блених кредитних або розрахункових карт; вимагання, скоєне з використанням мережі Інтернет та шкідливих програм; окремі види кібертероризму [8, с. 54-56].

Як уявляється, всі наведені кваліфікації мають певне науково-практичне значення та мають право на існування. Однак, слід брати до уваги і те, що сфера кіберзлочинності далека від врегулювання засобами кримінального права. Бракує і відповідних криміналістичних практик, що дозволяли б безпосередньо застосовувати описані класифікації. Наразі практично можливим уявляється застосування класифікацій, що грунтуються на об'єкті / предметі злочину, проте них слід пристосувати до класифікації злочинів за чинним Кримінальним кодексом. Використання такого підходу дозволяє запропонувати наступну класифікацію кіберзлочинів.

1. Злочини проти конституційних прав і свобод людини і громадянина. До них можна віднести порушення права на особисте та сімейне життя, порушення таємниці листування, порушення авторських і суміжних прав, що скоюються за допомогою комп'ютерних технологій чи мережі Інтернет.

2. Злочини проти життя та здоров'я населення, зокрема використання мережі Інтернет для розповсюдження заборонених чи обмежених у обігу речовин, таких як наркотики, психотропні речовини, ліки.

3. Злочини проти честі та гідності особи. До них можна віднести використання комп'ютерних технологій та мережі Інтернет для розповсюдження відомостей, що порочать честь та гідність особи.

4. Злочини проти власності. До них можна віднести викрадення грошових коштів з банківських рахунків, шахрайство та інші корисливі злочини, що ставлять на меті заволодіти власністю іншої особи з використанням комп'ютерних технологій і мережі Інтернет.

5. Злочини в сфері комп'ютерної інформації, зокрема неправомірний доступ до інформації, а також створення та використання шкідливих комп'ютерних програм.

6. Злочини проти суспільної моралі (найбільш відомим прикладом є виготовлення, зберігання й поширення порнографії, в тому числі дитячої).

7. Злочини проти безпеки держави, в тому числі, проти державної таємниці, скоєні з використанням комп'ютерних технологій чи мережі Інтернет.

8. Злочини терористичного характеру, зокрема заклики до тероризму, фінансування тероризму та безпосередньо акти кібертероризму.
Наведена класифікація не $\epsilon$ досконалою з точки зору криміналістики, адже вона виходить не стільки 3 характеристики діяння, скільки $з$ потреби кваліфікувати це діяння за кримінальним правом. Проте саме така класифікація дозволяє використати наявний понятійний апарат Кримінального кодексу для охоплення якомога більшої кількості вже виявлених чи потенційно можливих кіберзлочинів.

Висновки. Запропоновані криміналістичні класифікації кіберзлочинів слід поділяти підставою, що використовуються для класифікації. Більшість з них ґрунтується на виділенні спеціального об'єкту чи предмету кіберзлочинів. Поєднання такого підходу з чинним кримінальним законодавством України дозволяє створити комплексний підхід, що ґрунтується на існуючих в кримінальному праві об'єктах кримінального посягання (проти особи, проти власності, проти безпеки держави, тощо). Така класифікація потребує подальшого уточнення, проте саме вона уявляється найбільш виправданою з точки зору забезпечення криміналістичних заходів засобами кримінального й кримінально-процесуального права.

\section{Література}

1. Головин А.Ю. Криминалистическая систематика. Москва : ЛексЭст, 2002. 308 с.

2. Додатковий протокол до Конвенції про кіберзлочинність, який стосується криміналізації дій расистського та ксенофобного характеру, вчинених через комп'ютерні системи від 28.01.2003 р. URL: http://zakon.rada.gov.ua/ laws/show/994_687 (дата звернення: 10.11.2018).

3. Илюшин Д.А. Особенности расследования преступлений, совершаемых в сфере предоставления услуг Интернет : дисс. ... канд. юрид. наук : 12.00.12 / Волгоградский государственный университет, 2008. 233 с.

4. Конвенція про кіберзлочинність від 21.11.2001 р. URL: http://zakon.rada.gov.ua/laws/show/994_575. (дата звернення: 10.11.2018).

5. Мещеряков В.А. Основы методики расследования преступлений в сфере компьютерной информации : дисс. ... докт. юрид. наук : 12.00.12 / Воронежский государственный университет, 2001. 390 с.

6. Пашнев Д.В. Криминалистическая классификация преступлений, совершаемых с использованием компьютерной техники. Симферополь : Доля, 2004. 208 с.

7. Серёжкина А.Е. Психические состояния пользователей ЭВМ в процессе компьютеризированной деятельности : дисс. ... канд. психол. наук : 19.00.01 / Казанский государственный педагогический университет, 1998. 252 c.

8. Шевченко Е.С. Тактика производства следственных действий при расследовании киберпреступлений : дисс. ... канд. юрид. наук : 12.00.12 / Московский государственный юридический университет им. О.Е. Кутафина, 2016. 249 с.

9. Яковлев А.Н., Олиндер Н.В. Особенности расследования преступлений, совершённых с использованием электронных платёжных средств и систем : научно-методическое пособие. Москва : Олма, 2012. 187 с.

Довженко О. Ю., аспірант кафедри кримінального процесу одеського державного університету внутрішніх справ 